\title{
Presence of Toxocara eggs on the hair of dogs and cats
}

\author{
Semih ÖGE, Hatice ÖGE, Bahadır GÖNENÇ, Gökben ÖZBAKIŞ, Ceren YILDIZ
}

Ankara University, Faculty of Veterinary Medicine, Department of Parasitology, 06110, Ankara, Turkey.

\begin{abstract}
Summary: Toxocara canis and Toxocara cati, the common dog and cat ascarids, are zoonotic parasites. Humans can become infected through ingestion of infective eggs. It is generally accepted that human infection is caused as a result of direct contact with contaminated soil. However, recently, the eggs of Toxocara spp. have been found in the hair of dogs. This study was undertaken to determine the prevalence of Toxocara spp. eggs on the hair of dogs and cats. From 130 stray and owned animals, samples were taken from the perianal region, the caudal aspect of the hind limbs and the underside of the tail. In the hair of 49 dogs (49\%) and 4 cats (13.3\%) Toxocara spp. eggs were found. For the cat, total number of Toxocara eggs were 6. One of the egg recovered (16.7 \%) was embryonated and one (16.7\%) was unembryonated. A total of 857 Toxocara spp. eggs were found in dogs. 439 (51.2 \%) of the eggs recovered were unembryonated, 131 (15.3\%) were embryonating, 89 (10.4\%) were embryonated and $198(28.1 \%)$ were non-viable. Eggs of Taenia spp., Dipylidium caninum and Toxascaris leonina were also recovered 24, 6 and $15 \%$ of dog hair samples, respectively. As Toxocara spp. eggs were found in the hair of stray/owned dogs and cats, direct contact with dogs and cats may be a potential risk factor for transmission of Toxocara spp. eggs to humans.
\end{abstract}

Key words: Cat, direct contact, dog, eggs, hair, Toxocara spp.

\section{Kedi ve köpek tüylerinde Toxocara yumurtalarının varlığı}

Özet: Toxocara canis and Toxocara cati; köpek ve kedilerde yaygın olarak görülen, zoonoz askaritlerdendir. İnsanlar, larvalı yumurtaların sindirim yoluyla alınmasıyla enfekte olurlar. İnsan enfeksiyonları için genel kabul gören bulaşım yolu, kontamine toprakla direkt temastır. Ancak son zamanlarda, Toxocara spp. yumurtaları köpek tüylerinde bulunmuştur. Bu çalışma, köpek ve kedi tüylerinde Toxocara spp. yumurtalarının prevalansını belirlemek amacıyla yapılmıştır. 130 sokak ve sahipli hayvandan, perianal bölge, arka bacak bölgesi ve kuyruk altından tüy örnekleri toplanmıştır. 49 köpekte (\% 49) ve 4 kedide (\% 13.3) Toxocara spp. yumurtası bulunmuştur. Kedilerde toplam 6 Toxocara spp. yumurtası bulunmuş, biri larvalı (\% 16.7), biri (\% 16.7) canlıdır. Köpeklerde toplam 857 Toxocara spp. yumurtası bulunmuştur. Bunların 439'u (\% 51.2) canlı, 131'i (\% 15.3) embriyonal süreçte, 89’u (\% 10.4) larvalı ve 198'i (\% 28.1) ölü yumurtadır. Aynı zamanda köpek tüylerinde Taenia spp., Dipylidium caninum ve Toxascaris leonina yumurtaları da sırasıyla \% 24, \% 6 ve \% 15 bulunmuştur. Toxocara spp. yumurtalarının sokak/sahipli köpek ve kedi tüylerinde bulunması, köpek ve kedilerle direkt temasın insanlara Toxocara spp. yumurtalarının bulaşmasında potansiyel risk faktörü olabileceğini düşündürmektedir.

Anahtar sözcükler: Direkt temas, kedi, köpek, tüy, Toxocara spp., yumurta.

\section{Introduction}

Toxocara canis and Toxocara cati, that are common parasites of dogs and cats, respectively. They are zoonotic parasites known to infect human and cause visceral, neural, ocular, covert and asymptomatic toxocariasis $(5,16,23,27)$.

Worldwide, the prevalence rates of T.canis varied from $7.1 \%$ to $40.7 \%(7,9,25,32)$. The prevalence rates of T.canis and T.cati varied from $4.1 \%$ to $44.8 \%$ and $27.6 \%$ to $47.2 \%$ in Turkey, in respectively $(6,12,13)$.

The most widely recognized source of human infection is ingestion of contaminated food, water and soil. Children have the highest risk of infection as they have an increased opportunity of exposure to contaminated soil and sandpits while playing outdoors $(5,24,26,27)$. In addition, infection can also occur following ingestion of partial or whole paratenic host, such as raw livers of domestic animals and following ingestion of contaminated raw vegetables or fruits $(23,33)$. Direct contact with dogs and cats that harbour a patent Toxocara infection is usually not considered a risk, because the eggs need to mature 3-6 weeks before they are infective $(10,20,28)$. An alternative mode of transmission recently proposed is contact with embryonated eggs on a dog's hair in recent studies $(2,4,30,36)$. The presence of Toxocara spp. on dogs' and cats' hair as another possible source of infection, those were preliminary investigations and did not address whether Toxocara spp. eggs were likely to have been transfered to dogs' and cats' hair via selfcontamination, or picked up from soil.

The seroprevalence of toxocariasis in the human population has been reported to fluctuate between 2.2 and $92.8 \%$ depending on countries, study groups age and socio-cultural level (31). The prevalence of toxocariasis 
in the human population varies greatly between countries due to factors such as socio-economic status, level of development, local food habits and climate $(4,11,33)$. In addition to, seropositivity has been associated with picageophagia, rural residence, overcrowding, low level education and poverty (31). There are only few studies on seroprevalence in humans in Turkey, and the seroprevalence of Toxocara antibodies is greatly between 2.16 and $51.35 \%(11,19,21,22)$.

Wolfe and Wright (36) commented that if it was to be shown that eggs could embryonate on the hair of a dog, direct contact with dogs could be seen as an alternative explanation of the epidemiology of the disease. Recently, infective eggs have been found in the hair of dogs suggesting that direct contact with the coat of a contaminated dog could be an additional route of transmission $(4,30,36)$.

Until now, some workers have found T.cati eggs in cat hair but not embryonated eggs $(18,28)$. Although the pathogenic potential of T.canis well recognize $(8,16)$, that of T.cati requires further investigation in cats $(1,8,16)$.

Considering this, the aim of the present study was to evaluate the existance of T.canis and T.cati eggs attached to hair in the range of locations on the stray and owned dogs and cats' body, as well as to determine their developmental stage and related with the animals' charateristic.

\section{Materials and Methods}

Sample collection and egg detection: Between November at 2010 and June at 2011, 100 dogs (71 stray and 29 owned) and 30 cats (9 stray and 21 owned) were examined from random source (animal care shelter and owned dogs and cats) in Ankara, Turkey. The age and sex of each animal was recorded. The dogs and cats were classified into adults (above 1 year), young (from 6 months up to 1 year) and puppy/kitten (up to 6 months).

The samples of hair were clipped from the perianal region, the caudal aspect of the hind limbs and the underside of the tail and stored at $4{ }^{\circ} \mathrm{C}$ and examined within two weeks of collection. Hair samples not stained with feces were weighed and their ranged from 0.05 to $14.52 \mathrm{~g}$ with the mean value of 1.76 in all dogs and their ranged from 0.06 to $2.14 \mathrm{~g}$ with the mean value of $0.35 \mathrm{~g}$ in all cats. Eggs were recovered from the hair with a modification of the method of by Wolfe and Wright (36). The sample was examined using a compound light microscope under $\times 10$ and $\times 40$ magnification.

Eggs were classified into four groups depending on stage of development: non-viable (egg wall disrupted or egg not intact), unembryonated (intact egg with contents), embryonating (egg with two or more cell divisions) and embryonated (containing a larva). Egg containing visible larvae which had not fully matured were classed as embryonating.
Statistical analysis: Egg distributions by age-group of dogs and per gram of hair distribution both stray and owned dog are shown with mean, median and standart deviation values. The effect of factors affecting the presence of the egg, which was first performed univarite logistic regression model. Variable with P-value 0.25 or less from the univariate logistic regression analysis, to be appointed multivariate logistic regression. Odds ratios were calculated to assess the effect of dog type, sex and age-group with the presence of at least one Toxocara egg at any stage in dog's hair and factors with ratios given. Chi-square test was performed difference between number of egg distribution on sample sites. Statistical analysis was performed using Statistical for Windows version 7.1.

\section{Results}

A total of 390 hair samples were examined from 100 dogs and 30 cats over a period of 7 months. Toxocara eggs were found on the hair of dogs and cats with a prevalence of $49 \%$ and $13.3 \%$, respectively. The results of analysis of egg positive hair samples in dogs and cats, originating from random source dogs and cats, are presented Table 1 and 2. A total of 857 eggs were found in all dogs, 198 (28.1\%) of which were not viable, $439(51.2 \%)$ were unembryonated, $131(15.3 \%)$ were embriyonating and 89 (10.4\%) were embriyonated. A total of 857 eggs were found on all dogs examinated; 439 eggs from the tail bottom, 212 eggs from the perianal region and 206 eggs from the caudal aspect of hind limbs. However, the highest concentration of Toxocara spp. eggs was found in the tail bottom of stray and owned dogs, there was no significant difference in the between regions $(\mathrm{P}>0.005)$.

37 stray and 12 owned dogs had Toxocara spp. eggs present in their hair samples. However, 12 of the positives were owned animals -6 adults, 2 young and 4 puppies and 37 stray dogs- 29 adults, 5 young and 3 puppies, the statistical analysis in this study showed that there were no significant difference between in stray dogs and owned dogs ( $>0.05)$. In regard to sex, the sex ratio of the positives was 31 females and 18 males (63.2 $\%$ and $36.7 \%$, respectively) but there was no significant difference in the overall prevalence between males and females $(\mathrm{p}>0.05)$.

Odd ratios were calculated to assess the effect of dog type, sex and age-group with the presence at least on Toxocara spp. egg at any stage in dog's hair (Table 3). According to the odd ratios analysis, it was found that stray dogs had 0.54 times the odds of having Toxocara spp. eggs in their hair compared with domestic dogs. The odds of having both all eggs type of Toxocara spp. eggs presented in hair increase in puppies (o.r.= 2.52) dogs compared with adult dogs and descrease in young dogs (o.r. $=0.89$ ) compared with adult dogs. It was found that female dogs had 1.4 times the odds of having eggs in their hair compared with male dogs. 
Table 1. Densities of Toxocara eggs found on egg-positive hair samples.

Tablo 1. Yumurta-pozitif tüy örneklerinde Toxocara yumurtalarının yoğunluğu.

\begin{tabular}{|c|c|c|c|c|c|c|c|}
\hline \multirow{7}{*}{ DOG } & Hair sites & & Non-viable & Unembryonated & Embryonating & Embryonated & All eggs \\
\hline & Tail & Stray & 72 & 69 & 78 & 38 & 257 \\
\hline & bottom & Owned & 4 & 176 & 2 & - & 182 \\
\hline & Perianal & Stray & 25 & 11 & 4 & 13 & 53 \\
\hline & & Owned & 32 & 115 & 10 & 2 & 159 \\
\hline & Caudal aspect & Stray & 61 & 48 & 36 & 36 & 181 \\
\hline & of hind limbs & Owned & 4 & 20 & - & - & 25 \\
\hline All & Sites & & 198 & 439 & 131 & 89 & 857 \\
\hline \multirow{6}{*}{ CAT } & Tail & Stray & 1 & - & - & 1 & 2 \\
\hline & bottom & Owned & 2 & - & - & - & 2 \\
\hline & Perianal & Stray & - & - & - & - & - \\
\hline & & Owned & - & 1 & - & - & 1 \\
\hline & Caudal aspect & Stray & - & - & - & - & - \\
\hline & of hind limbs & Owned & 1 & - & - & - & 1 \\
\hline All & Sites & & 4 & 1 & - & 1 & 6 \\
\hline
\end{tabular}

Table 2. Quantity of Toxocara spp. eggs found on egg-positive hair samples.

Tablo 2. Yumurta-pozitif tüy örneklerinde Toxocara spp. yumurtalarının niceliği.

\begin{tabular}{|c|c|c|c|c|c|}
\hline & Non-viable & Unembryonated & Embryonating & Embryonated & All-eggs \\
\hline \multicolumn{6}{|l|}{ Puppy, $n=7$} \\
\hline Mean \pm SD & $23.77 \pm 51.89$ & $66.18 \pm 105.47$ & $15.98 \pm 16.79$ & $8.00 \pm$ & $88.50 \pm 129.62$ \\
\hline Median & 2.80 & 9.14 & 8.00 & 8.00 & 19.05 \\
\hline Minimum & 1.89 & 3.77 & 4.67 & 8.00 & 1.92 \\
\hline Maximum & 141.18 & 265.42 & 35.29 & 8.00 & 282.35 \\
\hline \multicolumn{6}{|l|}{ Young, $n=7$} \\
\hline Mean \pm SD & $4.01 \pm 4.33$ & $1.76 \pm 2.36$ & $7.92 \pm$ & $5.94 \pm$ & $6.67 \pm 11.15$ \\
\hline Median & 2.59 & 0.59 & 7.92 & 5.94 & 1.78 \\
\hline Minimum & 0.46 & 0.46 & 7.92 & 5.94 & 0.92 \\
\hline Maximum & 11.88 & 5.94 & 7.92 & 5.94 & 31.68 \\
\hline \multicolumn{6}{|l|}{ Adult, $n=35$} \\
\hline Mean \pm SD & $6.92 \pm 16.26$ & $4.55 \pm 8.42$ & $4.38 \pm 10.83$ & $8.51 \pm 18.39$ & $12.30 \pm 27.78$ \\
\hline Median & 2.18 & 1.56 & 0.89 & 0.99 & 2.62 \\
\hline Minimum & 0.28 & 0.20 & 0.20 & 0.07 & 0.23 \\
\hline Maximum & 80.0 & 37.50 & 40.0 & 62.50 & 140.0 \\
\hline \multicolumn{6}{|l|}{ All dogs, $n=49$} \\
\hline Mean \pm SD & $9.64 \pm 25.87$ & $14.43 \pm 46.80$ & $6.64 \pm 11.99$ & $8.28 \pm 16.81$ & $22.38 \pm 58.39$ \\
\hline Median & 2.44 & 1.81 & 0.99 & 1.82 & 3.30 \\
\hline Minimum & 0.28 & 0.20 & 0.20 & 0.07 & 0.23 \\
\hline Maximum & 141.18 & 265.42 & 40.0 & 62.50 & 282.35 \\
\hline
\end{tabular}

Mean and median values are all per gram of hair, SD Standart deviation

Table 3. Factors associated with the presence Toxocara spp. eggs on hair of dogs $(n=100)$.

Tablo 3. Köpek tüylerindeki Toxocara spp. yumurtalarının çeşitli faktörlerle ilişkilendirilmesi $(\mathrm{n}=100)$.

\begin{tabular}{lccc}
\hline Variable & \multicolumn{3}{c}{ All egg types } \\
& Odds ratio & $95 \% \mathrm{Cl}$ & $p$-Value \\
\hline $\begin{array}{l}\text { Dog type } \\
\quad \text { Stray vs. owned }\end{array}$ & 0.54 & $0.21-1.39$ & 0.2 \\
$\quad \begin{array}{l}\text { Sex } \\
\quad \text { Female vs. male }\end{array}$ & 1.40 & $0.61-3.18$ & 0.4 \\
$\quad$ Age & & & \\
$\quad$ Pupy & 2.52 & $0.62-10.14$ & 0.1 \\
$\quad$ Young & 0.89 & $0.29-2.73$ & 0.8 \\
$\quad$ Adult (base line) & & & \\
\hline
\end{tabular}

Table 4. Densities of Taenia spp., D.caninum and T.leonina eggs on hair from different sites of dogs.

Tablo 4. Köpeklerin farklı tüy bölgelerinde Taenia spp., D.caninum ve T.leonina yumurtalarının yoğunluğu.

\begin{tabular}{lcccc}
\hline & $\begin{array}{c}\text { Tail } \\
\text { bottom } \\
\text { (Stray/ } \\
\text { owned) }\end{array}$ & $\begin{array}{c}\text { Perianal } \\
\text { (Stray/ } \\
\text { owned) }\end{array}$ & $\begin{array}{c}\text { Caudal } \\
\text { aspect of } \\
\text { hind limbs } \\
\text { (Stray/ } \\
\text { owned) }\end{array}$ & $\begin{array}{c}\text { All sites } \\
\text { Total } \\
\text { (Stray/ } \\
\text { owned) }\end{array}$ \\
\hline Taenia spp. & $(165 / 3)$ & $(184 /-)$ & $(183 /-)$ & $535(532 / 3)$ \\
D.caninum & $(173 /-)$ & $(8 /-)$ & $(10 /-)$ & $191(191 /-)$ \\
T.leonina & $(115 / 92)$ & $(11 / 40)$ & $(187 / 9)$ & $454(313 / 141)$ \\
\hline
\end{tabular}


Table 5. Comparable studies of Toxocara egg hair infection in dogs and cats.

Tablo 5. Köpek ve kedi tüylerindeki Toxocara yumurta enfeksiyonları ile ilgili çalışmaların karşılaştırılması.

\begin{tabular}{|c|c|c|c|c|c|c|c|}
\hline References & Location & Species & $\begin{array}{l}\text { Number } \\
\text { tested }\end{array}$ & Prevalence & $\begin{array}{l}\text { Embryonated } \\
\text { eggs }\end{array}$ & $\begin{array}{l}\text { Total } \\
\text { eggs }\end{array}$ & $\begin{array}{c}\% \\
\text { embryonated }\end{array}$ \\
\hline Hasslinger et al. (1973) & Germany & Stray/owned cats & 17 & $1(6 \%)$ & - & - & - \\
\hline Wolfe and Wright (2003) & $\begin{array}{l}\text { UK and } \\
\text { Ireland }\end{array}$ & $\begin{array}{l}\text { Owned/farm/shelter } \\
\text { dogs }\end{array}$ & 60 & $15(25 \%)$ & 3 & 71 & 4.22 \\
\hline Roddie et al. (2008b) & Ireland & Stray dogs & 100 & $67(67 \%)$ & 120 & 39.12 & 0.3 \\
\hline $\begin{array}{l}\text { Aydenizöz-Özkayhan et } \\
\text { al. (2008) }\end{array}$ & Turkey & Owned dogs & 51 & $11(21.56 \%)$ & 5 & 62 & 8.06 \\
\hline \multirow[t]{2}{*}{ Overgauw et al. (2009) } & Netherland & Owned dogs & 148 & $18(12.16 \%)$ & 0 & - & 0 \\
\hline & & Owned cats & 59 & $2(3.38 \%)$ & 0 & - & 0 \\
\hline $\begin{array}{l}\text { Keegan and Holland } \\
(2010)\end{array}$ & $\begin{array}{l}\text { UK and } \\
\text { Ireland }\end{array}$ & Owned dogs & 182 & $16(8.79 \%)$ & 0 & 26 & 0 \\
\hline Amaral et al. (2010) & Brazil & Stray/owned dogs & 104 & $25(24 \%)$ & - & 15371 & - \\
\hline El-Tras et al. (2011) & Egypt & Stray/owned dogs & 120 & $23(19.16 \%)$ & 69 & 3223 & 2.14 \\
\hline \multirow[t]{2}{*}{ This study } & Turkey & Stray/owned dogs & 100 & $49(49 \%)$ & 89 & 857 & 10.38 \\
\hline & & Stray/owned cats & 30 & $4(13.3 \%)$ & 1 & 6 & 16.66 \\
\hline
\end{tabular}

Because of insufficient number of cats, the any statistical analysis was not carried out. Among the 30 cats, 16 of them came from adult animals, 8 from young and 6 from kitten. Overall, $13.3 \%$ of cats were positive for Toxocara eggs in their hair. Of the total number of Toxocara eggs, 4 (66.7\%) were classified as not viable, one $(16.7 \%)$ unembryonated and one $(16.7 \%)$ as embryonated (Table 1). In the positive cat group, 1 was young, 1 was adult and 2 were kittens. The sex ratio of positive animals was only 4 females. Finally, 3 of the positives were owned animals - 1 young and 2 kittensand 1 were stray adult cat.

In addition of these, the rates of contamination of dogs were $24 \%$ for Taenia spp. eggs, $6 \%$ for D.caninum eggs and $15 \%$ for T.leonina eggs. Among the 71 stray dog hair samples collected, Taenia spp. eggs were 22 (31 $\%)$, D.caninum eggs were $6(8.5 \%)$ and T.leonina eggs were $13(18.3 \%)$. In total, 454 T.leonina eggs were recorded, of which 70 (15.4\%) were non-viable, 140 (30.8\%) were unembryonated, 185 (40.7\%) were embryonating, 59 (13\%) were embryonated (Table 4).

\section{Discussion and Conclusion}

Recent studies have found embryonated T. canis eggs on the hair of dogs which suggested that direct contact with dogs may be important risk factor $(4,14,20,28,36)$. Regarding Toxocara spp. eggs in hair, only one study in dogs was carried out in Turkey (4). A prevalence of $22 \%$ in owned dogs was found. We have found the eggs of Toxocara spp. in $49 \%$ of dog hair samples. This figure is comparable with reported prevalence in other cities/countries (Table 5). The hair samples of dogs showed a higher prevalence of Toxocara spp. eggs than those recorded in similar studies except one study (30), who carried out a survey on an only stray dog population in the Ireland. The higher prevalences are found for both our study and the Irish investigation. The current studies found an increased risk of Toxocara eggs contamination in stray dogs compared with owned dogs $(2,14,30)$. Similar results were observed in our study, where $52.1 \%$ from stray dogs were positive for Toxocara spp. eggs. Moreover, we have found the eggs of embyonated of Toxocara spp. in $17.7 \%$ of hair samples in stray dogs. The higher prevalence in stray dogs is most likely attributable to the lack of anthelmintic treatment, contact with soil and grooming given to these animals.

It is reported that age is not related with the contamination of Toxocara eggs of the hair $(29,30,36)$ or in other words the eggs on the hair can be seen in all age groups but it is more common in less than one year old $(2,4,14,20)$. The result of the present study suggest that puppies are more likely to harbour eggs on their hair than young and adult. There are several reasons that can explain this higher percentage of eggs on puppies, they can be infected through transuterine and transmammary transmission (34). However, it has been found that young and adult dogs are still susceptible to Toxocara eggs infection, even if they have been previously infected as puppies (15); therefore young and adult dogs may still pose a risk to human health.

In the present study, there was no significant difference of Toxocara eggs on dog's hair between female and male. Nevertheless female dogs had 1.40 times the odds of having Toxocara spp. eggs in their compared with male dogs. This finding is again similar to that of Amaral et al. (2) who found the female dogs are more likely to harbour eggs on their hair than male dogs. According to Roddie et al. (30) there is no gender statistatically influenced Toxocara eggs prevalence found on the host. 
In our study, the average epg found on hair was approximately $22.38 \pm 58.39$ (min: 0.23 and $\max$ : 282.35) and embryonated eggs were $8.28 \pm 16.81$ (min: 0.07 and max: 62.50). Earlies studies, e.g. Wolfe and Wright (36) in the UK and Ireland recorded a percentage of 4.2 in pet, farm and shelter dogs, AydenizözÖzkayhan et al. (4) in Turkey observed a prevalence of embryonated T.canis eggs of $8.06 \%$ in pet dogs, Roddie et al. (30) in Ireland found a prevalence of $0.3 \%$ in stray dogs and El-Tras et al. (14) in Egypt observed $2.4 \%$ in stray and owned dogs. There was a difference between the density of T.canis egg on dogs' hair between stray and domestic dogs in this study. More eggs per gram of hair were observed on stray dogs; which may be related to frequent exposure of stray dog's hair to contaminated soil and environment and the absence of hygienic care.

In some reports it has been suggested that the epg of Toxocara in hair of infected animals is much higher than in soil $(4,30,36,37)$. Soil contamination of parks, playgrounds and sandpits with Toxocara spp. ranged from 4.2-62.5\% in studies conducted in different regions of Turkey $(3,17,26,35)$. In studies by AydenizözÖzkayhan (3) and Toparlak et al. (35) the mean rate of Toxocara eggs was found 0.6 per $30 \mathrm{~g}$ and 0.44 per $100 \mathrm{~g}$ in soil samples from the contaminated parks, respectively. A similar study by Oge and Oge (26) found that the number of Toxocara eggs ranged 1 to 10 per $50 \mathrm{~g}$ in soil samples from the public parks. The number of Toxocara spp. eggs was 22.38 per gram of hair in this study. This number seem to be much higher than those collected from the soil samples and may indicate that direct contact with dogs may be more effective in human toxocariasis.

Toxocara cati is a fecund worm and the proportion of cats that are infected can be high. For example, 27.6$47.2 \%$ of cats in Turkey were found to be infected $(6,13)$. A few studies have been performed in order to evaluted the hair contamination of the Toxocara eggs on the cats (Table 5). Toxocara eggs were found in the hair of $13.3 \%$ of the investigated cats. This value is high when compared with similar studies $(18,28)$ which found no embryonated eggs in hair of cats. We have found the unembryonated and embryonated egg of Toxocara spp. in hair of one stray and one owned cat. Overgaauw et al. (28) suggested that an indoor cat could be contaminated with Toxocara eggs via the shoes of the owner. But, the human don't come into the home with their shoes in Turkey. This indicates that self contamination could be, at least, in part responsible for the presence of eggs on the hair of owned cats. This study has provided evidence that cats, as in the case of dogs, are capable of carrying Toxocara spp. eggs on their hair.

Taenia spp., D.caninum and T.leonina eggs were found in the dog hair in this study. An interesting finding is the presence of Taenia spp. eggs in the hair samples. There is no any differentiation of Taenia spp. eggs from Echinococcus spp. eggs.
In conclusion, although soil contamination with Toxocara spp. eggs is significant responsible for human disease, eggs ingestion through direct contact with dog has been suggested as an alternative route of transmission for this zoonosis. Identification of embryonated Toxocara eggs and Taenia or Echinococcus eggs on dogs hair indicated that direct contact with dogs may be a potential risk factor for human exposure. In addition to self or environmental contamination is thought to be a route for helmint's eggs contamination of stray dog's hair. Whereas, in domestic dogs, the primary route of Toxocara eggs and other helminth's eggs adherence to hair is likely to be via self contamination. If the conditions become suitable, Toxocara spp. eggs may become embryonated in hairs of owned dogs. Education of the public about the zoonotic potential T.canis and/or T.cati and other helminth species, the prevention of environmental contamination with dogs and cats' feces, reduction of the stray dog and cat population and the use of anthelmintics and animal hygiene can help to prevent the contamination of human toxocariasis.

\section{References}

1. Akao N, Takayanagi TH, Suzuki R, Tsukidate S, Fujita K (2000): Ocular larva migrans caused by Toxocara cati in Mongolian gerbils and a comparison of ophtalmologic findings with those produced by T.canis. J Parasitol, 86, 1133-1135.

2. Amaral HLC, Rassier GL, Pepe MS, Gallina T, Villela MM, Nobre MO, Scaini CJ, Berne MEA (2010): Presence of Toxocara canis eggs on the hair of dogs: A risk factor for Visceral Larva Migrans. Vet Parasitol, 174, 115-118.

3. Aydenizöz-Özkayhan M (2006): Soil contamination with ascarid eggs in playgrounds in Klrlkkale, Turkey. J Helminthol, 80, 15-18.

4. Aydenizöz-Özkayhan M, Yağcı BB, Erat S (2008): The investigation of Toxocara canis eggs in coats of different dog breeds as a potential transmission route in human toxocariosis. Vet Parasitol, 152, 94-100.

5. Bowman DD (2009): Helminths. 179-184, 201-207. In: DD Bowman (Ed), Georgis' Parasitology for Veterinarians. Saunders Elsevier, St Louis, Missouri.

6. Burgu A, Tınar R, Doğanay A, Toparlak M (1985): $A$ survey for ecto-and endoparasites of stray cats. Ankara Üniv Vet Fak Derg, 32, 288-300.

7. Claerebout E, Casaert S, Dalemans AC, De Wilde N, Levecke B, Vercruysse J, Geurden T (2009): Giardia and other intestinal parasites in different dog populations in Northern Belgium. Vet Parasitol, 161, 41-46.

8. Coati N, Schnieder T, Epe C (2004): Vertical transmission of Toxocara cati Schrank 1788 (Anisakidae) in the cat. Parasitol Res, 92, 142-146.

9. Dai RS, Li ZY, Li F, Liu DX, Liu W, Liu GH, He SW, Tan MY, Lin RQ, Liu Y, Zhu XQ (2009): Severe infection of adult dogs with helminths in Hunan Province, China poses significant public health concerns. Vet Parasitol, 160, 348-350. 
10. Deplazes P, van Knapen F, Schweiger A, Overgaauw PAP (2011): Role of pet dogs and cats in the transmission of helminthic zoonones in Europe, with a focus on echinococcosis and toxocarosis. Vet Parasitol, 182, 41-53.

11. Doğan N, Dinleyici EÇ, Bor Ö, Özensoy S, Özbel Y (2007): Seroepidemiological survey for Toxocara canis infection in the Northwestern part of Turkey. Türkiye Parazitol Derg, 31, 288-291.

12. Doğanay A (1992): Check list of the parasites of cats and dogs in Turkey. Ankara Üniv Vet Fak Derg, 39, 336-348.

13. Doğanay A, Öge S (1993): The prevalence of ascariasis in stray dogs in Ankara. Ankara Üniv Vet Fak Derg, 40, 552562.

14. El-Tras WF, Holt HR, Tayel AA (2011): Risk of Toxocara canis in stray and domestic dog hair in Egypt. Vet Parasitol, 178, 319-321.

15. Fahrion AS, Staebler S, Deplazes P (2008): Patent Toxocara canis infections in previously exposed and in helminth-free dogs after infection with low numbers of embryonated eggs. Vet Parasitol, 152, 108-115.

16. Fisher M (2003): Toxocara cati: an underestimated zoonotic agent. Trends Parasitol, 19, 167-170.

17. Güçlü F, Aydenizöz M (1998): Çocuk parklarındaki kumların köpek ve kedi helminti yumurtalart ile kontaminasyonunun tespiti. Türkiye Parazitol Derg, 22, 194-198.

18. Hasslinger MA, Jonas D, Berger W (1973): Zur Stellung der Hauskatze in der Epidemiologie menschlicher Wurminfektionen unter besondere Berücksichtigung von Toxocara mystax. Tierarztl Umsch, 28, 26-33.

19. Kaplan M, Gödekmerdan A, Kalkan A, Erensoy A, Özde M (1999): Toxocara canis seroprevalence in Elazığ region. Firat Univ J Health Sci, 13, 51-54.

20. Keegan JD, Holland CV (2010): Contamination of the hair of owned dogs with the eggs of Toxocara spp. Vet Parasitol, 173, 161-164.

21. Kuman HA, Altıntaş N (1984): Ege bölgesinde serolojik olarak saptanan Toxocariasis olgulart. Türkiye Parazitol Derg, 1-2, 113-119.

22. Kustimur S, Al FD, Oğuzulgen K, Bakır H, Moral I, Turktaş H, Tuzun H (2007): Toxocara seroprevalence in adults with bronchial asthma. Trans Royal Soc Trop Med Hyg, 101, 270-274.

23. Lee ACY, Schantz PM, Kazacos KR, Montogomery SP, Bowman DD (2010): Epidemiologic and zoonotic aspects of ascarid infections in dogs and cats. Trends Parasitol, 26, 155-161.

24. Macpherson CNL (2005): Human behaviour and the epidemiology of parasitic zoonoses. Int J Parasitol, 35, 1319-1331.

25. Martinez-Moreno FJ, Hernandez S, Lopez-Cobos E, Becerra C, Acosta I, Martinez-Moreno A (2007): Estimation of canine intestinal parasites in Cordoba (Spain) and their risk to public health. Vet Parasitol, 143, 7-13.
26. Oge S, Oge H (2000): Prevalence of Toxocara spp. eggs in the soil of public parks in Ankara, Turkey. Dtsch Tierarztl Wschr, 107, 72-75.

27. Overgaauw PAM (1997): Aspects of Toxocara epidemiology: Human toxocarosis. Crit Rev Microbiol, 23, 215-231.

28. Overgaauw PAM, Zutphen L, Hoek D, Yaya FD, Roelfsema J, Pinelli E, van Knapen F, Kortbeek LM (2009): Zoonotic parasites in fecal samples and fur from dogs and cats in The Netherlands. Vet Parasitol, 163, 115122.

29. Roddie G, Holland C, Stafford P, Wolfe A (2008a): Contamination of fox hair with eggs of Toxocara canis. $\mathbf{J}$ Helminthol, 82, 293-296.

30. Roddie G, Stafford P, Holland C, Wolfe A (2008b): Contamination of dog hair with eggs of Toxocara canis. Vet Parasitol, 152, 85-93.

31. Rubinsky-Elefant G, Hirata CE, Yamamoto HJ, Ferreira MU (2010): Human toxocariasis: diagnosis, worldwide seroprevalences and clinical expression of the systemic and ocular form. Annal Trop Med Parasitol, 104, 3-23.

32. Sager H, Moret CHS, Grimm F, Deplazes P, Doherr MG, Gottstein B (2006): Coprological study on intestinal helminths in Swiss dogs: temporal aspects of anthelminthic treatment. Parasitol Res, 98, 333-338.

33. Smith H, Holland C, Taylor M, Magnaval JF, Schantz P, Maizels R (2009): How common is human toxocariasis? Towards standardizing our knowledge. Trends Parasitol, 25, 182-188.

34. Taylor MA, Coop RL, Wall RL (2007): Veterinary Parasitology (3rd ed). Blackwell Publishing, Oxford.

35. Toparlak M, Gargılı A, Tüzer E, Keleş V, Ulutaş Esatgil M, Çetinkaya H (2002): Contamination of children playground sandpits with Toxocara eggs in Istanbul, Turkey. Turk J Vet Anim Sci, 26, 317-320.

36. Wolfe A, Wright P (2003): Human toxocariasis and direct contact with dogs. Vet Rec, 152, 419-422.

37. Wolfe A, Wright P (2004): Parasitic nematode eggs in fur samples from dogs. Vet Rec, 154, 408.

Geliş tarihi: 07.01.2013 / Kabul tarihi: 05.03.2013

Address of correspondence:

Prof.Dr.Semih Oge

Ankara University, Faculty of Veterinary Medicine,

Department of Parasitology, 06110

Ankara, Turkey.

e-mail:soge@ankara.edu.tr 